\title{
Market Mechanism As Price Determinant (Analysis Thinking of Ibnu Taimiyah)
}

\author{
Sri Sudiarti \\ Department of Islamic Economic , State Islamic University, North Sumatera, Indonesia
}

\begin{abstract}
Ibnu Taimiyyah was a thinker and scholar of Islam who was born in Harran, on January 22, $1263 \mathrm{M}$ (10 or 12 Rabiul Awwal $661 \mathrm{H}$ ). He came from a highly educated family. He is the first Muslim scholars which gives great attention to the market and the price mechanism. Ibnu Taimiyyah in the discussion of price often use two terms, namely 'iwad al-mithl (equivalent compensation) and thaman al-mithl (equivalent price ). In price regulation, Ibnu Taimiyyah propose two forms of regulation that is a fair and legal price regulation and regulatory unfair (unjust) and illegal price regulation. This fact certainly raises the question: how does the concept of price and price fixing by the government according to Ibnu Taimiyyah? This study is a library research. Based on the analysis of the data found that the economy policy (ijtihad) made by Ibnu Taimiyyah was the appropriate / suitable policy (ijtihad) with the state of society at that time, based on the Qur'an, the Hadith, and thought at that time. in terms of price concept Ibnu Taimiyyah more emphasis on a fair price means the value of the price of an item is acceptable and commensurate with the goods sold in certain place and time. Regarding the regulation of prices, Ibnu Taimiyyah emphasized that the price defined benefit to all. and prior to price regulation should be the government held consultations with the representatives of the market and the people concerned. Graphically, according Ibnu Taimiyah price regulations aimed at protecting both parties and no one harmed.
\end{abstract}

Keywords - Market, Price, Ibnu Taimiyah

\section{INTRODUCTION}

Price theory in modern economies illustrates that the fair price or equilibrium price derived from the interaction between supply and demand in a perfect competition. Correspondingly, in the perspective of the Islamic concept of the price is not much different from the modern economy. But in Islam has always emphasized the role of ethics (moral values). Basically, Islam has illustrated that a fair price is a price that is shaped by market forces that run freely, which is a meeting between the forces of demand and supply.Market freely in the sense in which buyers and sellers compete with each other with the information flow running smoothly within the framework of justice, that no unjust or tyrannized. The meeting between the demand and the offer should be equally willing to let go, no one feels forced, deceived or there were errors in the transaction object of certain goods at a certain price level [1].It has also been described by Islamic scholars Shaykh al-Islam Ibn Taimiyah about the concept of price with the term tsaman al-mitsl and blasted actions that undermine market mechanisms which cause damage to the balance of the price, so the price is formed not because of natural market forces, but the price changes occur due to market distortions, known as market distortion. He described the changes in market prices in his book al-Hisbah fii al-Islam as follows:

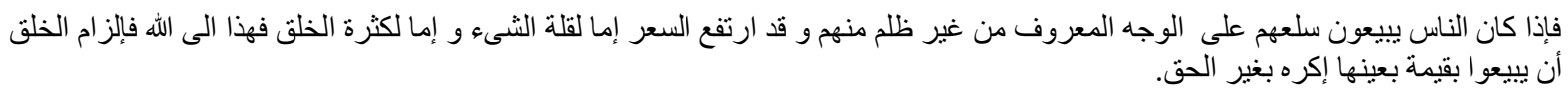

So when people sell their merchandise normally without using ways unfair (unjust) and then the price rose because of the influence of scarcity (ie reduction in supply) or because of an increase in the population (ie an increase in demand), the increase in these prices is the will of Allah. So in these conditions, forcing sellers to sell their merchandise at a specified price is not justified coercion [2].

The phrase "the normal way without using unfair ways (al-bathil)" indicates that the equivalent price it should be a reasonable price and is really happening in the market that are not accompanied by fraud, for a reasonable price just happened to competitive market (perfect market) and the only practice that is full of scams that can lead to an increase in prices [3].Theoretically, there is no significant difference between the modern economy with the economy of Islam against the concept of price. The concept of price is fundamentally the same, the price is reasonable or balanced price derived from the interaction between the forces of demand and supply in a perfect competition.

Complex market distortions in the modern economic system sometimes given birth imperfect competition in the market. In sunnatullah indeed, if perfect competition is running, the balance of the price in 
the market will be realized by itself. But sunnatullah also, that man - in this case as the market participants - it's not perfect. So in practice, many found irregularities destructive behavior of market equilibrium.Theoretically there are two types of policies are commonly applied in modern economies (conventional) that market intervention and price intervention. Price intervention policy is also divided into two types of policies, namely, floor price policy in which the government sets the level of the lowest price of an item, while the price is above the market price [4].Regarding the price intervention, Ibn Taimiyah distinguish two types of prices intervention, the unfair and legally flawed price intervention and fair and lawful price intervention. Unfair and legally flawed price intervention is the price intervention done when rising prices caused by free market competition, the scarcity of supply or the increase in demand. While the fair and lawful price intervention is considered fair if not to cause mayhem against the seller or the buyer [1].

\section{METHODOLOGY}

This study is a library research. This study included into bibliographic research is descriptive analytic thoroughly describe the biography of Ibnu Taimiyyah and contribute their thoughts with regard to the concept of price and pricing by the government. Data about the thoughts of Ibnu Taimiyyah in economic terms, especially in terms of prices and market mechanisms traced in his Al-Hisbah Fi Al-Islam and serve as the primary data. While the data related to this study traced the secondary sources and studies earlier in the works of scholars, researchers and historians who wrote about Ibnu Taimiyyah. After a successful data are collected, grouped, categorized and analyzed carefully.

\section{1}

\section{RESULT AND DISCUSSION}

Ibn Taymiyya And His Economy Thought

Ibn Taimiyyah full name is Ahmad bin Abul Halim bin Abdus Salam bin Abdullah bin Muhammad bin al-Khadhr bin Muhammad bin al-Khadhr bin Ali bin Abdullah ibn Taimiyyah Al-Harrani ad-Dimasyqi [5]. He was born in Harran, on January 22, 1263 M (10 or 12 Rabiul Awwal $661 \mathrm{H})$. He came from a highly educated family [1]. His father Abdul al-Halim, his uncle Fakhruddin and his grandfather Majduddin is a great scholar sect Hanabilah and author of several books. His family fled to his birthplace in the year $1262 \mathrm{AD}$, before the arrival of the Mongol army and sought refuge in Damascus. At the time of Ibn Taymiyya was only 7 years old [6].Signs of intelligence has been reflected in his personality from his childhood. From childhood, he spent his time in sincerity and hard work to memorize the Qur'an, Hadith, Fiqh and Arabic until he was good at that. He always follow the teachings of adh-Dzikri, listen and learn about the hadiths and also atsar [7].

The focus of attention Ibn Taimiyah lies in society, the moral foundation and how they should bring themselves according to sharia. For that task, Ibn Taymiyah suggested that the government and the scholars together to guide and supervise and encourage people. He also discussed various matters related to economic behavior, such as contract and efforts to obey them, the prices reasonable and fair, market supervision, public finance, and the role of the state in fulfilling the needs of its people live.

To further ensures the operation of market mechanisms and regulation of prices completely, the role of government is very important. Ibn Taimiyah has a framework that is consistent in the opinion stating that Islamic financial services, both the system and the law, are an integral part of the governance system and The constitutional. From here we can see that Ibn Taimiyah has deep thoughts related to economics (sharia).In exchange for the economy, the focus attention of Ibn Taimiyah focused on the justice that can only be realized if all parties make a contract by mutual agreement. To be meaningful, this agreement should be based on adequate information. Morality as ordered religion must require no coercion, no cheating, no taking advantage of a state of fear, or ignorance of one of the parties to a contract. When these rules were adhered to, the market price happens is reasonable and fair in terms of supply detained absence to raise prices.View of Ibn Taimiyah on public obligations also include discussions of setting money, rules on weights and measures, price controls, as well as consideration of higher taxes in an emergency.Generally, the economic views of Ibn Taimiyah tends to be normative. However, there are some economic insights that can be categorized as positive economic outlook. In this regard, Ibn Taimiyah is fully aware of the role of supply and demand in determining prices. He also noted the influence of indirect taxes and how the tax burden should be shifted from the seller to bear the tax to buyers who had to pay more for goods that are taxable [8].Ibn Taimiyah asserted that everyone must be guaranteed the adequacy of his life and with the minimum standards, so he was able to serve the almighty God and live in dignity. At the same time, he stressed the need for fairness. He stressed the responsibility of each person, as well as the state, as both should cooperate with each other and must not harm each other. Then he said, justice is a value that must be respected by all nations. He said "the entire population agree that the consequences of injustice is gloom and the fruit of justice is a monument to the people". Ibn Taimiyah discusses the principles of economic problems in two books, namely, Al-Hisbah fil Islam (Islamic Police Organization in Islam) and Al-Siyasah Syar'iyyah fi Al-Rai Al-Islah wa'l-Ra'iyah (Law pablik and private in Islam). In the first 
book, he discusses about the market and government intervention in economic life. In the second book, he discusses the problem income and public finance.

\subsection{Concept of Price According to Ibn Taimiyah}

A fair price according to Ibn Taimiyah is worth the price of goods / services where people sell merchandise and the price generally accepted as being commensurate with the goods sold or other similar goods particular place and time [1]. It can be understood from his book al-WH, as follows:

فإذا كان الناس يبيعون سلعهم على الوجه المعروف من غير ظلام منهم و قد ارتفع السعر إما لقلة الثىى و إما لكثرة الخلق فهذا الى الله فإلزام الخلق

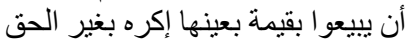

If residents sell their goods in normal ways (normal), without using unfair ways (acts of injustice) then the price has increased both because at least the supply of goods or due to population growth (demand), then it is solely for Allah. So in these conditions, forcing traders to sell their goods at a certain price is coercion is not justified [2].

The purpose of the normal ways (fair), traders should sell his wares in a manner that is fair and in accordance with the rules in force in the market without any unjust actions or dishonesty of a merchant. Wrongdoers here indicates the existence of elements that are banned by law as lying, treasonous. As for which includes for example reducing the dose / scales, deceptive in making something (factory), sale and purchase and debts. The increase in price is due at least inventory (supply) or because the population is increasing (demand), indicating that the increase is a rise in prices naturally without any elements of price bubbles or follow distorts the market, the price increase is categorized as price increases reasonable. Thus, according to Ibn Taimiyah forcing traders to sell their goods at a certain price is imposed legally incorrect. Because of the absence of factors (indicators) that damage the market price.

The indicators that could damage the market mechanism and consequences of the destruction of the market price according to Ibn Taimiyah is as follows [2]:

1. Ghaban Faahisy, which utilizes the consumers who do not know the price (Jahil bi-Ass si'r) prevailing in the market. So sellers have gained the upper by stupidity / ignorance of the buyer so that prices rise.

2. Ihtikar, namely to take the opportunity in the purchase of food that humans need to be a rare and hide from the public and want the price high.

3. The coalition between traders, which sent most traders to bid, praised the merchandise sold trader and bargains at a high price so that buyers eager to buy.

A fair price occurs only in a competitive market, because the price of competitive markets is the tendency reasonable price. Ibn Taimiyah said that if the people selling merchandise at normal price (the price increase affected by the lack of inventory due to the decreasing supply of goods), then things like this do not require any regulations on prices. Because of the price increase is a rise in prices fair and were in perfect competition, with no element of speculation [9]. As example, Ibn Taimiyah states:

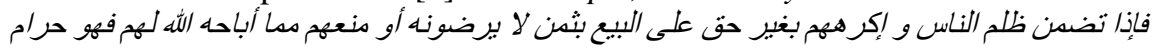

If there is a tyranny of the population and forcing the traders sell their wares at a price set without any basis that would enable or forbid them to sell goods that allowed Allah to them then forbidden to force them.

This indicates that people have complete freedom to enter and exit the market and are entitled to do any kind of buying or selling as long as no acts of unlawful shara'. Ibn Taimiyah very supportive over the suppression of monopolistic elements in the market and strongly opposes any form of collusion and the coalition is going on between the trader and the buyer or certain parties. Furthermore, he stressed the need for knowledge of the market and merchandise [2].On the other hand Ibn Taimiyah condemn their product counterfeiting and fraud in advertising, at the same time, support the homogeneity and standardization of products. He has a clear concept of good behavior and orderly market, with knowledge, honesty, fair play rule, and freedom of choice as a basic element [10] . Some of the implications of the doctrine of economic freedom in Islam concerned with market as envisaged Ibn Taimiyah as follows [11]:

1. People can enter and exit the market freely

2. The level of sufficient information on market forces and merchandise (commodity) is necessary.

3. The elements of monopoloti must be eliminated from the market.

4. Within the limits of freedom, he acknowledges the increase in supply and demand caused by prices.

5. Any deviation from the implementation of economic freedom are honest, like perjury, weighing improper and bad intentions criticized Muslim authors.

Ibn Taimiyah noted several factors that affect demand and consequently the price, as translated by Adiwarman Karim such as [12]:

1. The desire of the people (al-raghabah) against different types of goods and always changing. These changes correspond to a rare or not a requested item. The fewer the number of goods available will be increasingly in demand by the public. 
2. The number of enthusiasts (demander / tullab) to an item. If the number of people who want a more and more goods, the price of goods will increase, and vice versa.

3. Weak or strong need for a large or small items as well as the level and size requirements. If the needs of large and strong, prices will rise. Conversely, if the needs of small and weak, prices will drop.

4. The quality of the buyers. If the buyer is a rich and reliable in paying the debt, given the lower price. Conversely, given a higher price if the buyer is a man who is bankrupt, like stalling the payment of debts and reneging on debt.

5. The type of money used in the transaction. The price will be lower if pemabayaran done using the common currency used (naqd ra'ij) than the money that is rarely used.

6. The purpose of the transaction which requires ownership reciprocal (mutual) between the two sides. The prices of goods that have been available on the market is lower than the price of a good ynag not yet exist in the market. Similarly, the price will be lower if the payment is made in cash rather than payment is made in installments.

7. The size of the costs to be incurred by the manufacturer or seller. The greater the charge required by the manufacturer or seller to produce or obtain goods will be higher the given price, and vice versa.

There are two themes that are often found in Ibn Taymiyya discussion on the issue price, there are [9]:

a. Equal compensation / fair ('iwad al-mitsl): a fair compensation is commensurate replacement which is a value equivalent price of an object according to the customs. Compensation equivalent measured and assessed by similar things without any addition and subtraction, this is where the essence of justice.

b. Equal price / fair (tsaman al-mitsl). The fair price is worth the price where people sell goods is generally accepted as being commensurate with the goods sold or similar goods other particular place and time

Justice desired by Ibn Taimiyah associated with Islamic principles in fiqh qawaid called La dharar wa

la dhirar meaning not harmed and do not harm others, then to do justice will prevent the occurrence of acts of injustice.There are similarities between the thought of Ibn Taimiyah with modern economics against government policies in the market mechanism. In the mechanism of the market, the price level is determined by the forces of demand and supply. The meeting point of this curve is called the equilibrium price.

Ibn Taimiyah and modern economy strongly agreed if the government does not intervene in the price for a market mechanism that occurs where the demand and supply curves meet without any interference or in other words there is a change in price due to change in supply genuine and demand genuine. However, if the price changes are not due to supply genuine and demand genuine, then the government must carry out market intervention [9].Government policies towards market prices are often performed and recognized in the economic system there are two policies are common practice. The policies include market intervention policies and the intervention price. In intervening in the market there is no significant difference between thinking Ibn Taimiyah and modern economy. In modern economic policy pursued by the government, namely the market operation in which the government held an open market so that the market price can be controlled and the price is expected to return to normal.However, according to Ibn Taimiyah if the price change is due to natural factors such as their Ihtikar practice, is the act in which people hoard goods to sell fewer goods at higher prices so that profits above normal profits. If this happens, then the market operations conducted by the government according to Ibn Taimiyah is not a best solution but the government must intervene prices.In the policy of intervention price, thinking Ibn Taimiyah and modern economy there is a difference. Graphically, Taimiyah's price protects both parties and no one harmed. However, in modern economic policy in intervention prices may lead to one of the injured party. As if the government set the price below the market price then it would lead to doubt the producer to sell his wares.

\section{CONCLUSION}

The concept of price proposed by Ibn Taimiyah is not much different from what has been formulated by modern economists. The only difference is the emphasis on ethics and morals. In principle, a fair price occurs when the supply and demand occurs naturally and balanced (equilibrium price). A fair price according to Ibn Taimiyah is the value of the price of goods which the seller sells his wares and generally accepted as being commensurate with the goods sold or other similar items in place and a certain time.Ibn Taimiyah and very modern economists agree that if the government did not interfere in pricing for market mechanisms go naturally without any disturbances from the traders and from the buyer. Ibn Taimiyah recommend to the government to take measures or supervision of the market price in the event of fraud or any disturbances that lead to inflate the price. That is, prices which occurred not because of the strength of demand and supply, but because of their manipulation and exploitation or acts of injustice.

\section{REFERENCES}

[1] A. Adiwarman, H. Karim, Islamic Micro Economic, Jakarta:PT Raja Grafindo Persada, 2008, pp. 181.

[2] I. Taimiyah, Al-Hisbah Fi Al-Islam, Kairo, Al-Maktabah Al-Ilmiyah, 1976, pp. 18. 
[3] A. A. Karim, Hystory of Islamic Economic, Jakarta:PT Raja Grafindo Persada, 2008, pp. 358.

[4] Team LP3EI UII Yogyakarta, Islamic Economic, PT RajaGrafindo Persada:2008, pp. 337.

[5] I. Taimiyah, Fatwa-fatwa Ibn Taimiyah, Edition of Indonesia, Trans.. Izzuddin Karimi, Tahqiq. Amir alJazzar \& Anwar al-Baz, Jakarta:Pustaka Sahifa,2008, pp. 19.

[6] E. Amelia, Hystory of Islamic Economic Strating Classic to Contamporary Period, Depok: Gramata Publishing, 2010, pp. 206.

[7] Al-Hafizh 'Umar bin 'Ali Al-Bazzar, Syaikhul Islam...Theologian Persone Rabbani, Trans.. A. M. Miftah, Jogja: Al-Fath Media, 2009, pp.12.

[8] Karim, Thinking History,pp.19-20.

[9] Euis, Thinking History, pp. 212

[10] Ibid, pp.13

[11] M. Kahf, Islamic Economic (Analysis of Economic System Function). Trans.. M. Husein, Yogyakarta:Pustaka Pelajar,1995, pp. 55

[12] Adiwarman, Thinking History, pp. 366 